\title{
Changes in Pectic Components, Ascorbic Acid, Pectic Enzymes and Cellulase Activity in Ripening and Stored Guava (Psidium guajava $\mathbf{L}$.)
}

\author{
Golam MowlaH* and Saburo ITOo* \\ * Laboratory of Postharvest Physiology and Preservation of Fruits and Vegetables, \\ Kagoshima University, 1-21-24 Korimoto, Kagoshima 890
}

\begin{abstract}
This study was designed to observe chemical changes along with pectin-degrading and cellulolytic enzyme activities in two cultivars of guava during fruit maturation, ripening and storage. Total pectin content was $345.9-396.1 \mathrm{mg} / 100 \mathrm{~g}$ during maturation and $704.8-804.0 \mathrm{mg} / 100 \mathrm{~g}$ in ripening in both cultivars. Protopection and water soluble pectin were predominant in matured and ripened fruits, respectively. Alcohol insoluble solids and acidity decreased in both cultivars; and $\mathrm{pH}$ was 4. 2-5. 0 in white and 4.0-5.2 in pink varieties during maturation, ripening and storage. Guava polygalacturonase and cellulase showed maximum activity at $\mathrm{pH} 5.5$ and 6.0 , respectively. Ripe guava showed polygalacturonase activity recognized only remarkably at full ripe and the activity increased further in stored samples. Guava indicated a little pectinesterase and cellulase activity and these were found to increase sharply at the stage from maturation to ripening. During the stages from immature to full ripe on the tree, ascorbic acid content increased gradually in both cultivars. During stages from ripe to full ripe, and storage for 10 days at $20^{\circ} \mathrm{C}$; in white cultivar total ascorbic acid, ascorbic acid and dehydroascorbic acid contents were 149.9-273.5, 126.7-224. 0 and 23.3-49.5 $\mathrm{mg} / 100 \mathrm{~g}$, respectively; and in pink cultivar these were 172.6-270.3, 146.2-203.8 and 26.4-66.5 mg/ $100 \mathrm{~g}$, respectively. Ascorbic acid content was found to increase remarkably in stored fruits until decay or senescence of the fruits started.
\end{abstract}

Pectic substances are drawing attention because of their role in maintaining the texture of fruits $^{1)}$ and in influencing the quality of products. Numerous studies were made regarding the effect of pectins on firmness of fresh fruits and processed fruit products ${ }^{2-4}$ ) and in assessing the pectic constituents of fruits ${ }^{5 / 8)}$. Peaches were found to have different proportions of water soluble and water insoluble pectin depending on their varieties at different stages of maturation and ripening ${ }^{277}$. Thickening and gelling properties of pectin present in fruits affect the rheological properties of jam and nectar products. Until now no precise information is available on the pectic constituents of guava during maturation and ripening as characterized by varietal changes but this type of information is earnestly demanded by the guava processors. Further- more, fruits ripening and softness are attributed to the activities of pectic enzymes ${ }^{8 / 122}$. In case of tomato fruit cellulase was found to be associated with softening ${ }^{13) 14}$ ) and evidences of cellulase activity was found also in various fruits ${ }^{15) \sim 17}$.

During the previous studies investigations were made on polyphenols and polyphenoloxidase; and sugar components and related enzymes invertase and amylase at stages of fruit maturation, ripening and storage in two cultivars of guava ${ }^{18)(1)}$. The present work was performed with the same varieties at their different stages of maturation, ripening and storage to determine quantitatively the changes in pectic and cellulolytic enzymes along with some chemical analysis.

* Present address where correspondence is to be made: Laboratory of Food Science \& Technology, Faculty of Agriculture, Tokyo University of Agriculture, 1-1-1 Sakuragaoka, Setagaya-ku, Tokyo 156 


\section{Materials and Methods}

\section{Samples and sample preparation}

Guava (Psidium guajava L.) samples of white $\mathrm{C}-1-16$ and pink $\mathrm{C}-1-40$ seedling varieties were collected and graded as immature (picked on September 24), mature (picked on October 8), ripe (picked on October 8), full ripe (picked on October 22) and stored according to the procedure described previously ${ }^{18) 19}$. The fruits picked on October 8 were graded mature and ripe depending on size and degree of ripeness as mentioned earlier ${ }^{18}$. The term stored was used for full ripe guava samples stored for 8 days at $20^{\circ} \mathrm{C}$ in small polyethylene bags with opened mouth. For storage experiment (1-11 days) the same procedure was followed with guava harvested on November 4. The strawberry (cv. Harunoka) samples were picked at their picking time of consumption (April 7) and stored (1-7 days) at the same storage conditions used for guava.

Preparation of alcohol insoluble solids (AIS)

AIS were prepared and collected according to the procedure of SHEwFELT ${ }^{20}$ ) with boiling ethanol to inactivate the enzymes from each of the representative samples and the prepared AIS were stored in desiccator at $10^{\circ} \mathrm{C}$.

\section{Determination of pectic substances}

The colorimetric carbazole method of $\mathrm{McCомB}$ and $\mathrm{MCCREADY}^{21}$ ) was followed according to the modification made by BITTER and MUIR ${ }^{22)}$ for the determination of pectic substances and the results were expressed as $\mathrm{mg}$ of $\alpha-\mathrm{D}-$ galacturonic aicd monohydrate (AGA) per 100 $\mathrm{g}$ of fruit $(\mathrm{mg} / 100 \mathrm{~g})$. Versene-pectinase carbazole method of MCCREADY and MCCOMB ${ }^{6)}$ was used to determine the total pectin with the following modification. AIS were added with $5 \%$ versene solution (ethylenediamine tetraacetic acid tetrasodium salt), and the mixture was adjusted to $\mathrm{pH} 11.5$ with $1 \mathrm{~N}$ $\mathrm{NaOH}$ and de-esterified at $30^{\circ} \mathrm{C}$ for $2 \mathrm{~h}$ and then acidified to $\mathrm{pH} 3.0$ with $1 \mathrm{~N} \mathrm{HCl}$. To the acidified mixture pectinase (10\% of AIS) was added. After adding a few drops of toluene, the mixture was allowed to stand overnight at $25-27^{\circ} \mathrm{C}$ and then filtered and the filtrate was made up to the required volume and then was used for determination of total pectin.

\section{Protopectin determination}

Protopectin was considered to be water insoluble fraction but soluble in versenepectinase. Water soluble pectin from the AIS was extracted according to the procedure of Postlmayr et al. ${ }^{2)}$ and the residue was used as the material for protopectin determination and the results were found to be similar to that determined by the method of difference.

Determination of acidity and $p H$

Tritratable acidity was determined with phenolphthalein as the indicator at $\mathrm{pH}$ 8.1. The $\mathrm{pH}$ of the extracted juice was determined with a single electrode $\mathrm{pH}$ meter.

Analysis of ascorbic acid

As guava contained dehydroascorbic acid (DHAA), the indophenol method of BessEY ${ }^{23}$ ) alone was not sufficient to investigate the total ascorbic acid (TAA) content of guava. TAA was determined according to the DNP colorimetric method of ROE and OESTERLING ${ }^{24)}$ with some modifications. The weighed amount of minced guava samples was extracted with $5 \%$ metaphosphoric acid $\left(\mathrm{HPO}_{3}\right)$ containing 1\% thiourea. The aliquot portions were first added with $0.02 \%$ of 2,6-dichloroindophenol sodium salt solution and then with $2 \%$ thiourea solution ( $2 \%$ thiourea in $5 \%$ metaphosphoric acid). Then $2 \%$ DNP solution ( $2 \%$ solution of 2,4-dinitrophenylhydrazine in $9 \mathrm{~N}_{2} \mathrm{H}_{4}$ ) was added. The reaction mixtures were warmed up at $50^{\circ} \mathrm{C}$ for $70 \mathrm{~min}$, cooled sufficiently at ice temperature and then added with $85 \% \mathrm{H}_{2} \mathrm{SO}_{4}$ taking care that the temperature did not rise. After color development absorbance of the reaction mixtures was measured at $520 \mathrm{~nm}$ with a Shimadzu Spectrophotometer. This procedure gave TAA (ascorbic acid plus DHAA). Ascorbic acid (AA) was represented by the difference between the amount for TAA and that determined without addition of 2,6dichloroindophenol solution a procedure for determining the DHAA. The concentration of ascorbic acid was determined from a standard curve of $\mathrm{L}$-ascorbic acid and expressed as $\mathrm{mg}$ per $100 \mathrm{~g}$ fruit. 
Preparation of acetone powders and sam. ples

Acetone powder, prepared as mentioned in the earlier paper ${ }^{18}$, was extracted with $4 \%$ sodium chloride in presence of insoluble polyvinylpyrrolidone ( $10 \%$ of acetone powder) by centrituging at $14000 \mathrm{rpm}$ for $15 \mathrm{~min}$ at $-5^{\circ} \mathrm{C}$. The same extraction was repeated two times more. The pooled extract was made up to the desired volume (protein content 45.1-127.7 $\mu \mathrm{g} / \mathrm{ml})$.

\section{Enzyme assay}

Polygalacturonase (PG) (poly- $\alpha-1,4$-galacturonide glycanohydrolase, EC 3.2.1.15): Routinely the enzyme reaction mixture $(3 \mathrm{ml})$ consisted of $1 \mathrm{ml}$ of enzyme extract, $1 \mathrm{ml}$ of $0.25 \%$ pectic acid solution and $1 \mathrm{ml}$ of $0.1 \mathrm{M}$ acetate buffer ( $\mathrm{pH}$ 5.5). The increase in reducing groups was measured by the copper reduction method ${ }^{25)}$. The activity was given as increased reducing power and expressed as the liberation of microgram equivalent of reducing groups taking $\alpha$-D-galacturonic acid as a standard in $24 \mathrm{~h}$ under the above specific reaction conditions.

Pectinesterase (PE) (pectin pectyl-hydrolase, EC 3.1.1.11): The acetone powder was dispersed in $0.15 \mathrm{M}$ sodium chloride in presence of insoluble polyvinylpyrrolidone at $\mathrm{pH} \quad 7.5$ and the dispersion was stirred continuously for $15 \mathrm{~min}$ and then centrifuged for $15 \mathrm{~min}$ at $14000 \mathrm{rpm}$ at $-5^{\circ} \mathrm{C}$. The clear supernatant was used to determine the pectinesterase activity according to the principle of KERTESz ${ }^{26)}$ as follows. Citrus pectin solution (1\%) was prepared with $0.15 \mathrm{M}$ sodium chloride, adjusted to $\mathrm{pH} 7.5$. The stock solution of $1 \%$ citrus pectin was kept in a refrigerator at $4^{\circ} \mathrm{C}$ with the addition of a few drops of toluene and warmed up to room temperature of 26-30 ${ }^{\circ} \mathrm{C}$ prior to use. Thirty $\mathrm{m} l$ of $1 \%$ citrus pectin solution of $\mathrm{pH} 7.5$ was warmed at $30^{\circ} \mathrm{C}$ in a constant temperature water bath. Then $5 \mathrm{ml}$ of the enzyme extract was added and the $\mathrm{pH}$ was immediately readjusted to 7.5 and the time was noted. The alkali was added at the rate required to keep the mixture at $\mathrm{pH} 7.5$ for 15. min. PE unit was expressed as $\mathrm{ml}$ of alkali mulitiplied by normality of alkali consumed by
$1 \mathrm{~m} l$ of the added enzyme solution in $15 \mathrm{~min}$ which represents the $\mathrm{mEq}$ of ester hydrolyzed per $15 \mathrm{~min}$ per $\mathrm{ml}$ of enzyme solution.

Cellulase $[1,4-(1,3 ; 1,4)-\beta-D$-glucan 4 -glucanohydrolase, EC 3.2.1.4]: Cellulase activity was measured according to HinTon and PRESSEY ${ }^{16)}$ using the same enzyme extract of $P G$. Enzyme reaction mixture was composed of 1 $\mathrm{m} l$ of enzyme solution, $5 \mathrm{~m} l$ of $0.5 \%$ carboxymethyl cellulose sodium salt (CMC salt) solution with $0.1 \mathrm{M}$ citrate-phosphate buffer of $\mathrm{pH} 6.0$ and incubated at $30^{\circ} \mathrm{C}$ in water bath in glass tubes. A control containing $1 \mathrm{ml}$ of extract heated for $5 \mathrm{~min}$ in boiling water was run with each sample. After $24 \mathrm{~h}$ incubation the tubes were heated in boiling temperature for $10 \mathrm{~min}$, cooled, centrifuged and then $5 \mathrm{ml}$ of the supernatant was put into an OstwaLd Viscometer placed in a constant temperature water bath at $30^{\circ} \mathrm{C}$ and the viscosity was measured. The percent loss of viscosity was supposed as being proportional to the cellulase activity. The CMC salt stock solution was preserved at $4^{\circ} \mathrm{C}$ with the addition of a few drops of toluene.

A study indicated that guava cellulase had maximum activity at $\mathrm{pH}$ 6.0.

\section{Results and Discussion}

Table 1 showed that there was a variation in pectin content in two cultivars of guava. Pectin contents changed throughout the whole period of maturation, ripening and storage in both varieties. In ripening pectin content was higher in white than in pink but during storage pectin content was slightly higher in pink than in white. It shows that pectin in pink is resistant to storage exposure than in white, which may be due to the differences in chemical composition. Protopectin content was $83.5-96.9 \%$ of the total pectin during development and maturation, and the WSP was $3.0-16.4 \%$ during these times in both the varieties. This high retention of protopectin with less transformation to WSP during guava maturation conforms with the findings of Nightingale et $a{ }^{2}{ }^{27}$ ) and Postlmayr et al. ${ }^{2)}$ in peach varieties. On the other hand, WSP increased with the beginning of ripening and 
Table 1 Pectic substances in quava varieties during maturation, ripening and storage

\begin{tabular}{|c|c|c|c|c|c|c|c|c|c|c|}
\hline \multirow{3}{*}{$\begin{array}{l}\text { Degree } \\
\text { of } \\
\text { maturation }\end{array}$} & \multirow{2}{*}{\multicolumn{2}{|c|}{$\begin{array}{c}\mathrm{TP} \\
(\mathrm{mg} / 100 \mathrm{~g} \mathrm{~F})\end{array}$}} & \multicolumn{4}{|c|}{ Water soluble pectin } & \multicolumn{4}{|c|}{ Protopectin } \\
\hline & & & \multicolumn{2}{|c|}{$\mathrm{mg} / 100 \mathrm{~g} \mathrm{~F}$} & \multicolumn{2}{|c|}{$\% \mathrm{TP}$} & \multicolumn{2}{|c|}{$\mathrm{mg} / 100 \mathrm{~g} \mathrm{~F}$} & \multicolumn{2}{|c|}{$\% \mathrm{TP}$} \\
\hline & W & $\mathbf{P}$ & $\mathrm{W}$ & $\mathrm{P}$ & W & $\mathbf{P}$ & W & $\mathrm{P}$ & W & $\mathrm{P}$ \\
\hline Immature & 360.7 & 345.9 & 12.2 & 10.4 & 3.4 & 3.0 & 348.4 & 335.4 & 96.5 & 96.9 \\
\hline Mature & 396.1 & 363.6 & 65.1 & 53.1 & 16.4 & 14.6 & 330.9 & 310.4 & 83.5 & 85.3 \\
\hline Ripe & 791.9 & 704.7 & 486.5 & 409.4 & 61.0 & 57.3 & 315.3 & 305.3 & 39.0 & 42.6 \\
\hline Full ripe & 804.0 & 720.0 & 604.1 & 560.7 & 68.9 & 70.9 & 299.9 & 259.2 & 31.1 & 29.0 \\
\hline Stored & 723.6 & 727.2 & 616.9 & 580.9 & 84.5 & 79.8 & 116.6 & 146.3 & 15.4 & 20.1 \\
\hline
\end{tabular}

$\mathrm{W}=$ white, $\mathrm{C}-1-16$ seedling variety; $\mathrm{P}=$ pink, $\mathrm{C}-1-40$ variety; $\mathrm{T} P=$ total pectin

contents expressed as milligram per 100 gram fruit weight.

Table 2 Chemical composition of guava varieties during maturation, ripening and storage

\begin{tabular}{|c|c|c|c|c|c|c|}
\hline \multirow{2}{*}{$\begin{array}{c}\text { Degree } \\
\text { of } \\
\text { maturation }\end{array}$} & \multicolumn{2}{|c|}{$\begin{array}{l}\text { AIS } \\
(\%)\end{array}$} & \multicolumn{2}{|c|}{$\begin{array}{c}\text { Acidity } \\
(\%)\end{array}$} & \multicolumn{2}{|c|}{$\mathrm{pH}$} \\
\hline & $\mathrm{w}$ & $P$ & W & $\mathbf{P}$ & $\mathrm{W}$ & $\mathbf{P}$ \\
\hline Immature & 10.60 & 17.99 & - & - & - & - \\
\hline Mature & 8.90 & 8.47 & 0.42 & 0.56 & 4.2 & 4.0 \\
\hline Ripe & 5.50 & 5.41 & 0.37 & 0.45 & 4.2 & 4. 1 \\
\hline Full ripe & 5. 10 & 4.60 & 0.35 & 0.42 & 4. 6 & 5.0 \\
\hline Stored & 4.80 & 4.20 & 0.32 & 0.33 & 5.0 & 5.2 \\
\hline
\end{tabular}

$\mathrm{W}=$ white, $\mathrm{C}-1-16$ variety; $\mathrm{P}=$ pink, $\mathrm{C}-1-40$ variety; Acidity expressed as citric acid; ' - '=determination could not be made.

at full ripe it became $68.9-70.9 \%$ of total pectin, during storage it reached $79.8-84.5 \%$ of total pectin while protopectin was 29. 0-31.1 $\%$ at full ripe and $15.4-20.1 \%$ at storage, leading to marked softness of the fruits. The same phenomenon was also observed by Dolendo et al. ${ }^{28}$ ) in case of ripening avocado, and by SterLing and $\mathrm{KALB}^{29}$ ) in case of Elberta peaches. From the correlationship between the changes in solubility of pectin and calcium, DOESBURG ${ }^{30)}$ suggested that solubilization of pectin during ripening of apples was possibly caused by movement of calcium in the cell wall also resulting to changes in $\mathrm{pH}$ and organic acids ${ }^{31}$. Chemical analyses with respect to AIS, pH and titratable acidity of the guava varieties are given in Table 2 .

As shown in Fig. 1 guava PG and cellulase possessed maximum activity at $\mathrm{pH} 5.5$ and
6. 0 , respectively.

Fig. 2 indicated that in fruit maturation PG activity was static but at the inception of ripening, activity of this enzyme started and rose sharply at full ripe and continued to increase during storage. Attempts were also made to determine PG activity of guava by viscosimetric method, but no detectable activity was observed. The determination of PG activity of guava by measuring the liberated reducing groups, therefore, was more sensitive, indicating that guava $\mathrm{PG}$ is an exo-PG which was also found to be true in case of citrus ${ }^{32}$. PG activity was recognizable with the initiation of ripening. The same phenomenon was also reported by BABBIT et al. ${ }^{39)}$ in case of tomato ripening. However, the increase in $P G$ activity at ripening imparts that the $P G$ activity might lead the fruit to ripen, and also the PG activity may be responsible for some processing effects of guava products such as, cloud stability of guava juice. During storage PG activity increased inducing softness effect to the guava. PG activity was found to increase during softening of the tissues for dates ${ }^{34}$, avocados ${ }^{11}$ ) and tomatoes ${ }^{\mathrm{Sb})}$. Among the two varieties the pink had higher activity than the white. The increased PG activity during ripening and storage of guava is likely due to the transformation of inactive insoluble protein to soluble protein $^{34)}$ caused by intrinsic auto-catalytic processes. Or the disintegration of the tissue during storage releases or opens the blockade of catalyst or active enzyme surface which as a whole increases the PG activity. Although 


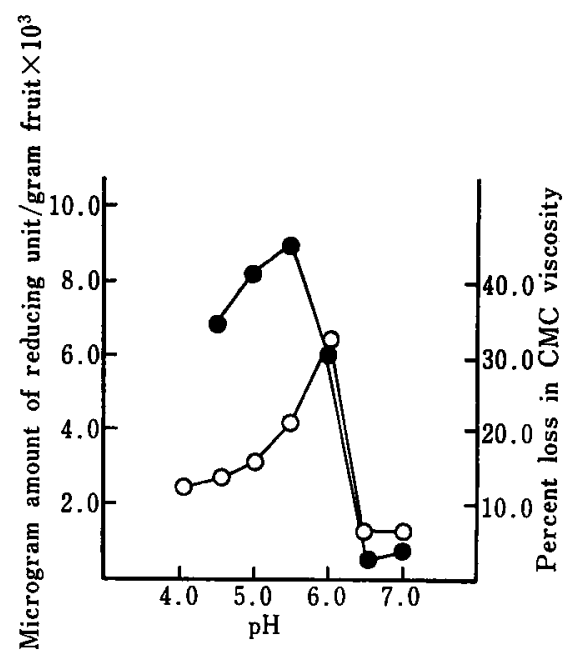

Fig. 1 The $\mathrm{pH}$ vs activity curves for polygalacturonase and cellulase of guava fruit

-: polygalacturonase; 0 : cellulase

$\mathrm{pH}: 4.0-5.5$ with acetate buffer $(0.1 \mathrm{M})$

6. 0-6.5 with citrate-phosphate buffer $(0.1 \mathrm{M})$

7. 0-8. 0 with phosphate buffer (0.1M)

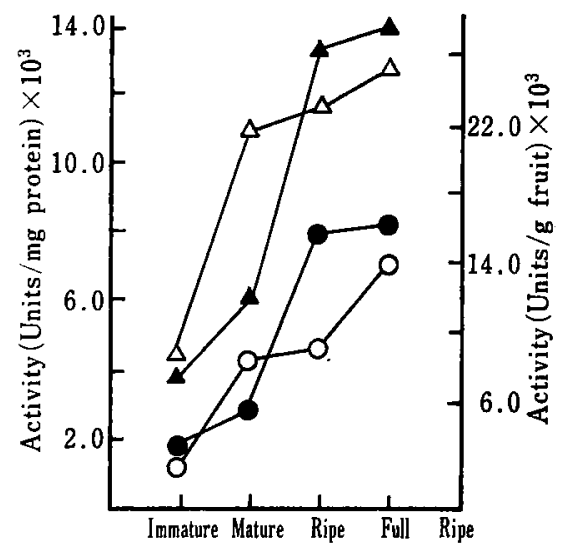

Fig. 3 Pectinesterase activity in guava at stages of maturation and ripening

-: White variety, activity (units/mg protein)

$\mathrm{O}$ : Pink variety, activity (units/mg protein)

$\Delta$ : White variety, activity (units/g fruit)

$\Delta:$ Pink variety, activity (units/g fruit)

there is less possibility for the direct biosynthesis of enzyme for the increased PG activity, the disappearance, removal, or leaching

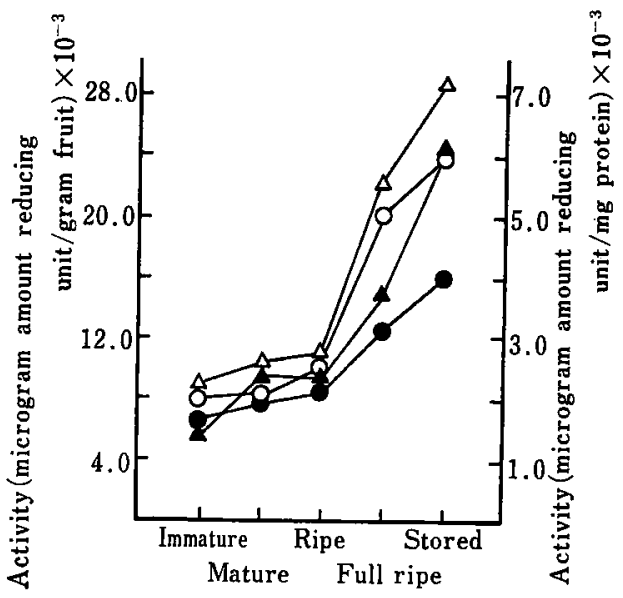

Fig. 2 Polygalacturonase activity in two varieties of guava at stages of maturation, ripening and storage

- : White variety, activity (units/g fruit)

$O$ : Pink variety, activity (units/g fruit)

$\Delta$ : White variety, activity (units/mg protein)

$\Delta$ : Pink variety, activity (units/mg protein)

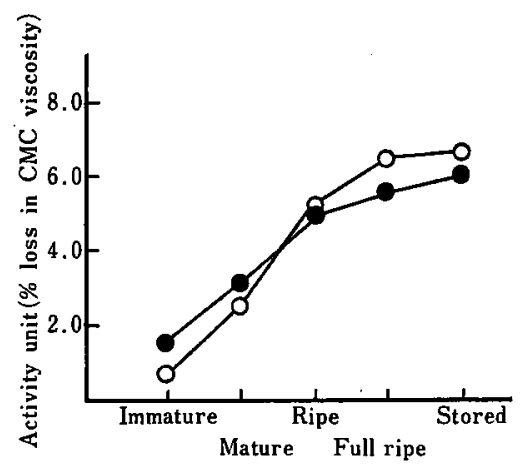

Fig. 4 Cellulase in guava varieties at maturation, ripening and storage

- White and $O$ : Pink varieties

out of the PG inhibitory factor during softening of the tissue may have role in increasing PG activity during storage ${ }^{34}$. Fig. 3 represents the PE activity in the two varieties of guava. Guava, as a whole, possessed low PE activity. It started at maturation and increased 
faster at ripening than at full ripe which was different from PG.

As shown in Fig. 4, cellulase activity changed differently from PG and PE activity. It started to increase from immature stage with remarkable increase in maturation and ripening, and then slowly increased at full ripe and the increase was very slow during storage. The existence of cellulase activity in guava during fruit development and maturation coincided with the viewpoints of BABBIT et al. ${ }^{\text {s3) }}$ that cellulase activity was present in young fruit. It could be said that guava cellulase reached almost its maximum activity before full ripening of the fruit. As the enzymatic degradation of cellulse could be an important process during ripening, the increase in cellulase activity in ripening implied that cellulase in collaboration with pectic enzymes affects the ripening and thereafter softening of guava fruit. The same phenomenon was suggested also for peach $^{16)}$ but with deviation from tomatoes as in case of tomato the cellulase activity increased only slightly at ripening ${ }^{36}$. These patterns of activity of $\mathrm{PG}$ and cellulase at the ripening paralleled the instances of invertase and amylase $^{19}$. PRATT and GoESCHL ${ }^{37}$ reported that the sharp increases of these hydrolytic enzymes at the early stage of ripening are a typical phenomenon occurring in climacteric fruits. Considering these changes coupled with the changes in chemical composition including carbohydrates ${ }^{18 / 19}$ ) it can be suggested that these two cultivars of guava belong to climacteric group of fruits.

In genaral ascorbic acid contents of both cultivars varied widely at stages from maturation to ripe. TAA content was 96.4-149.9 $\mathrm{mg} / 100 \mathrm{~g}$, and AA content was 54.2-126.7 $\mathrm{mg} / 100 \mathrm{~g}$ in white variety; and these were 106. 5-172. 6 and $72.5-146.2 \mathrm{mg} / 100 \mathrm{~g}$, respectively, in pink variety (Fig. 5). However, stored samples showed increased ascorbic acid contents (e.g. white variety: TAA 273.5, AA 224.0, and DHAA $49.5 \mathrm{mg} / 100 \mathrm{~g}$; and pink variety: TAA 270.3, AA 203.8, and DHAA $66.5 \mathrm{mg} / 100 \mathrm{~g}$ ). It is evident that these two varieties of guava contained a quite high quantity of TAA as was found in other

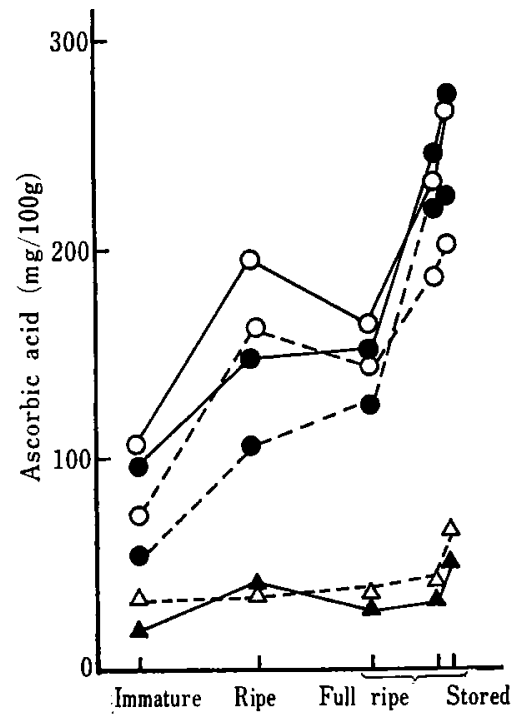

Fig. 5 Ascobic acids content of guava at maturation, ripening and storage at $20^{\circ} \mathrm{C}$

- - White, total ascorbic acid (TAA)

O- O: Pink, TAA

-- $\bullet$ : White, ascorbic acid (AA)

O- - O: Pink, AA

$\Delta-\Delta$ : White, dehydroascorbic acid (DHAA)

$\Delta-\cdots-\Delta$ : Pink DHAA

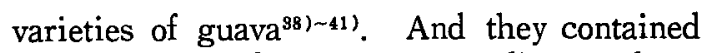
a small amount of DHAA. According to above stated results TAA increased considerably in stored samples. To investigate the increasing trend with storage, experiments were performed with two varieties of tree ripened guava fruit stored under the same experimental conditions and the results are shown in Fig. 6. The results indicated a sharp incresae in ascorbic acid with storage time. For comparison with guava, the same postharvest experiment was done with strawberry (cv. Harunoka) during storage. As shown in Fig. 7, there was no increase of ascorbic acid in strawberry, although increase was observed in guava determined under the same conditions. It shows that ascorbic acid accumulation was continued in stored tree ripened guava. Increased PG activity in stored samples along with other biochemical changes may lead ascorbic acid synthetase or transformation 


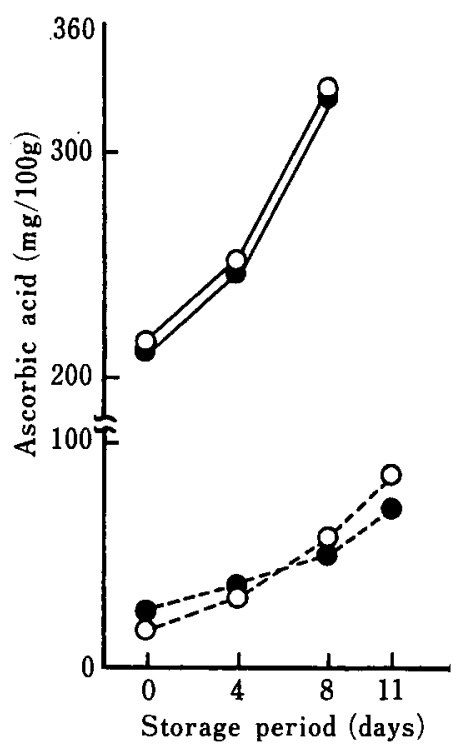

Fig. 6 Changes of ascorbic acids in ripe guava (harvested on Nov. 4) during postharvest storage at $20^{\circ} \mathrm{C}$

0 - 0 : Pink, total ascorbic acid (TAA)

-1 White, TAA

O---O: Pink, dehydroascorbic acid (DHAA)

-.- White, DHAA

reaction to continue until decay or senescence of the fruit was started. It can be said that biosynthetic regulation along with translocatory system might be a pathway for ascorbic acid accumulation in guava. TANuSI and YAmaмото ${ }^{42)}$ reported that citrus Sudachi can utilize D-galacturonic acid as a precursor of ascorbic acid when D-galacturonic acid was added with the homogenates of fruit stored under nitrogen atmosphere. This indicates that increased hydrolytic activity of PG resulting to liberation of galacturonic acid could have some effect on increasing of asorbic acid in stored guava samples.

Acknowledgement: The authors are indebted to the management of the Ibusuki Botanical Station, Kagoshima for rendering facilities to utilize the guava samples grown in that station during different stages of the fruit growth. The authors gratefully acknowledge Prof. Tetsujiro OваRA of Tokyo University of Agriculture, Tokyo for kindly reviewing the manuscript and offering valuable suggestions.

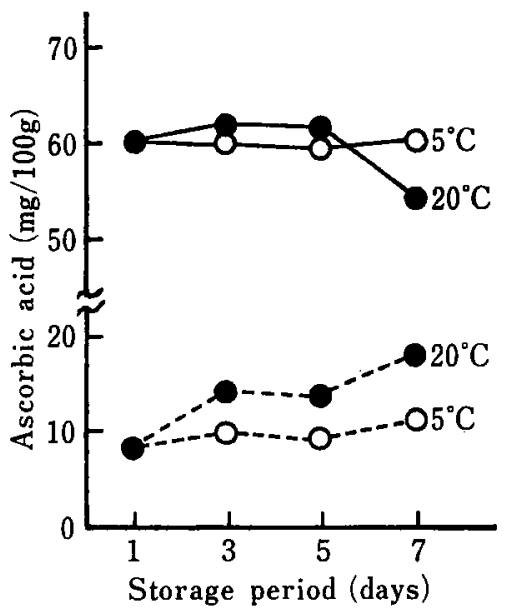

Fig. 7 Postharvest (harvested on April 7) changes of ascorbic acid contents in strawberry (cv. Harunoka) during storage

- : Total ascorbic acid

- - : Dehydroascorbic acid

\section{References}

1) KeRTEs2, Z. I.: The pectic substances, (Interscience Pub., New York), (1951).

2) Postlmayr, H. L., Luh, B. S. and Leonard, S. J.: Food Technol, 10, 618 (1956).

3) Luh, B.S. and Dastur, K. D.: J. Food Sci., 31, 178 (1966).

4) Doessurg, J. J.: Pectic substances in fresh and preserved fruits and vegetables, I. B.V.T. Communication No. 25, (Institute for Research on Storage and Processing of Horticultural Produce, Wageningen, The Netherland), (1965).

5) McCready, R.M. and McСomb, E. A.: Anal. Chem., 24, 1986 (1952).

6) McCready, R. M. and McComb, E. A.: Food Res., 19, 530 (1954).

7) Shewfelt, A. L., Paynter, V.A. and Jen, J. J.: J. Food Sci., 36, 573 (1971).

8) Whillenberger, R. T. and Nutting, G. C.: Food Technol., 11, 19 (1957).

9) Сocking, E. C. and Gregory, D. W.: J. Exp. Bot., 14, 504 (1967).

10) Новson, G. E.: Biochem. J., 92, 324 (1964).

11) Reymond, D. and Phaff, H. J.: J. Food Sci., 30, 266 (1965).

12) Patterson, M. E., Doughty, C. C., Graham, S. O. and Allan, B.: Proc. Am. Soc. Hort. Sci., 90, 498 (1970).

13) Hal., C. B.: Bot. Gaz., 125, 156 (1964). 
14) Dickinson, D. B. and McCollum, J. P.: Nature, 203, 525 (1964).

15) Hasegawa, S. and Smolensky, D. C.: J. Food Sci., 36, 966 (1971).

16) Hinton, D. M. and Presseley, R.: J. Food Sci., 39, 783 (1974).

17) Kertesz, A. I., Eocore, M. and Fox, G.: Food Res., 24, 14 (1959).

18) Mowlah, G. and Iтoo, S.: Nippon Shokuhin Kogyo Gakkaishi (J. Jpn. Soc. Food Sci. Technol.), 29, 413 (1982).

19) Mowlah, G. and Iroo, S.: Nippon Shokuhin Kogyo Gakkaishi (J. Jpn. Soc. Food Sci. Technol.), 29, 472 (1982).

20) Shewfelt, A. L.: J. Food Scl., 30, 573 (1965).

21) МсСомв, E.A. and McCready, R. M.: Anal. Chem., 24, 1630 (1952).

22) Bitter, T. and Muir, H. M.: Anal. Biochem., 4, 330 (1962).

23) Bessey, O. H.: J. Biol. Chem., 126, 771 (1938).

24) Roe, J.H. and Oesterling, M. T.: J. Biol. Chem., 152, 511 (1944).

25) Spiro, G. R.: Methods in Enzymol., 8, 3 (1960).

26) Kertesz, Z. I. : Methods in Enzymol., 1, 18 (1955).

27) Nightingale, G. T., Addons, R. M. and Blake, M. A.: N. J. Agric. Exp. Stan., Bull. 494, 2 (1953).

28) Dolendo, A. L., Luh, B. S. and Pratt, H. K.: J. Food Sci., 31, 332 (1966).

29) Sterling, C. and Kalb, A. J.: Bot. Gaz., 121, 111 (1959).

30) Doesburg, J.J.: J. Food Sci., 8, 206 (1957).

31) Pressey, R., Hinton, D. M. and Avants, J. K.: J. Food Sci., 36, 1070 (1971).

32) Rrov, J.: Plant Physiol., 53, 312 (1974).

33) Babit, J.K., Powers, M. J. and Patterson, M. E.: J. Am. Soc. Hort. Sci., 98, 77 (1973).

34) Hasegawa, S., Maier, V. P., Kaszycki, H. P. and CRAWford, J.K.: J. Food Sci., 34, 537 (1969).

35) Hoвson, G. E.: Phytochemistry, 6, 1337 (1967).

36) Soвotka, F.E. and Watada, A. E.: J. Am. Soc. Hort. Sci., 96, 705 (1971).

37) Pratt, H. K. and Goeschl, J. D.: Annu. Rev. Plant Physiol., 20, 541 (1969).

38) Itoo, S., Yamagucht, T., Ооhata, J. T. and Ishinata, K.: Bull. Fac. Agric. Kagoshima Uuiv., 30, 47 (1980).

39) Wenkam, N. S. and Miller, C. D.: Hawail Agric. Exp. Stan. Bull. No. 135, 32 (1965).
40) Boyle, F. P., Seagrave-Smith, H. and Miller, C. D.: Hawaii Agric. Exp. Stan. Bull. No. 111, 5 (1957).

41) Katayama, O.: Nippon Shokuhin Kogyo Gakkaishi (J. Jpn. Soc. Food Sci. Technol.), 25, 176 (1965).

42) Tanusi, S. and Yamamoto, M.: J. Jpn. Soc. Food Nutr., 34, 579 (1981).

(Received Nov. 24, 1982)

グアバ果赛の成熟・追熟並びに貯萩中におけるペクチ ン, アスコルビン酸, ペクチン関連酵素及びセルラーゼ 活性の変化について

$$
\begin{gathered}
\text { ゴーラム モーラ・伊藤三郎 } \\
\text { (鹿児島大学農学部) }
\end{gathered}
$$

グアバの白色及び桃色 2 品種について成熟・追熟並び 貯蔵中における化学的变化，ペクチン関連酵素及びセル ラーゼの変化を調べた。

1. グてバ果実中の全ペクチン量は両品種共に成熟時 では 345.9-396. $1 \mathrm{mg} \%$ ，追熟時では 704.7-804.0 mg\% であった。なお，成熟及び追熟果におけるぺクチンの主 成分はプロトペクチン及び可溶性ペクチンであった。

2. フルコール不溶物量及び酸度は成熟・追熟並びに 貯蔵中に減少した。一方, $\mathrm{pH}$ は白色種では 4.20 から 5.00, 桃色種では 4.00 から 5.20 に上昇した。

3. グTバ果実のポリガラクチェロナーゼ及びセルラ 一ゼの最適 $\mathrm{pH}$ は各々 5.5 及び 6.0 であった。ポリガラ クチュロナーゼ活性は追熟及び貯蔵中に著しく増加し た。ペクチンエステラーゼ及びセルラーゼは 末熟果で は，その活性はわずかであったが，成熟及び追熟中に増 加した。

4. 未熟果から完熟果へと樹上で成育中にアスコルビ ン酸含量は次第に増加を示した。その後 $20^{\circ} \mathrm{C} て ゙ 10$ 日間 貯蔵したところ，全アスェルビン酸，還元型および酸化 型フスコルビン酸量は白肉種では各々 149.9-273.5, 126.7-224.0 及び 23.3-49.5 mg\%, 桃色種では各々 166.5-270.3，146.2-203.8 及び 26.4-66.5 mg\% とな り，著しく增加することを見出した。このビタミンC含 量の増加は，貯蔵中に果実がも老化，腐敗を生ずるまで続 くことが認められた。 